\title{
METODE TALFIQ MANHAJI MUI DALAM FATWA
}

\author{
Muhammad Iqbal \\ Institut Agama Islam Negeri (IAIN) Kendari, Indonesia \\ Email: muhammadiqbal@iainkendari.ac.id
}

\begin{abstract}
The use of talfiq method is debatable among some scholars because it has the potential to create a new law from the existing one determined by the Imam of Madzhab. This study aims to investigate how effective the MUI talfiq manhaji method is in responding to the worship issues during the corona virus disease 2019 (COVID-19) pandemic. This research employs a descriptive-qualitative method by explaining the MUI statement determination method with in-depth analysis, then linking it to the Imam Mujtahidin statement in Islamic law. The results indicate that the talfiq manhaji method used by the MUI is effective in reducing public anxiety, especially related to worship procedures during COVID-19 pandemic. Talfiq manhaji method is a paradigmatic breakthrough addressing the challenges which can be reported and accounted for in normative and social way as well.
\end{abstract}

\section{Keywords: Talfiq method, Statement, Covid-19}

\begin{abstract}
Abstrak
Metode talfiq oleh sebagian ulama ditolak secara mutlak penggunaannya, dikarenakan berpotensi mewujudkan hukum baru dari apa yang telah disepakati oleh Imam Madzhab, Namun, sebagian lain membolehkan secara mutlak dikarenakan tidak adanya keharusan untuk mengikuti pendapat Imam tertentu dalam suatu permasalahan. Penelitian ini bertujuan untuk melihat seberapa efektif metode talfiq manhaji MUI dalam merespon problematika ibadah di masa Corona Virus Disease 2019 (COVID-19). Metode deskriftif-kualitatif dengan menjelaskan metode penetapan fatwa MUI dengan analisis yang mendalam, lalu dikaitkan dengan metode penetapan fatwa Imam Mujtahidin dalam hukum Islam. Hasil penelitian menunjukkan bahwa Metode talfiq manhaji yang digunakan MUI terbukti efektif dalam meredam kegelisahan masyarakat khususnya terkait prosedur ibadah pada situasi terjadi wabah COVID-19. Metode talfiq manhaji ini merupakan terobosan paradigmatik yang mampu menjawab tantangan zaman dan dapat dipertanggung jawabkan secara normatif dan sosial sekaligus.
\end{abstract}

Kata Kunci: Talfiq Manhaji, Fatwa, COVID-19 


\section{A. Pendahuluan}

Sebagai sebuah lembaga yang memiliki otoritas keagamaan di Indonesia, Majelis Ulama Indonesia (MUI) dituntut untuk memberi pencerahan keumatan dan merespon persoalan hukum Islam aktual yang muncul di tengah-tengah masyarakat. Berdasarkan rekam jejaknya, MUI telah banyak mengeluarkan fatwa, meskipun dalam perjalanannya kewenangan fatwa MUI belum mendapatkan posisi yang semestinya dalam kehidupan berbangsa dan bernegara. Sejak penyebaran wabah COVID-19 pertama kali hingga 8 provinsi di Indonesia, para Ulama beserta cendekiawan muslim Indonesia dalam berbagai bidang telah mengeluarkan 3 Fatwa di bulan Februari 2020. Pertama: Fatwa Nomor 14 Tahun 2020 tentang Penyelenggaraan Ibadah dalam Situasi Terjadi Wabah COVID-19, Kedua; Fatwa Nomor 17 Tahun 2020 tentang Pedoman Kaifiat Shalat bagi Tenaga Kesehatan yang Memakai Alat Pelindung Diri (APD) saat Merawat dan Menangani Pasien COVID-19 dan Ketiga; Fatwa Nomor 18 Tahun 2020 tentang Pedoman Pengurusan Jenazah (Tajhiz Aljanaiz) Muslim yang Terinfeksi COVID-19.

COVID-19 adalah jenis penyakit menular yang disebabkan oleh coronavirus, merupakan jenis virus baru dan tidak pernah terbayangkan sebelumnya. Penyebarannya yang cepat mengharuskan para pemangku kebijakan mengatur strategi terbaik dalam mencegah penyebarannya. Kesadaran dan keberagaman umat Islam di dunia pada dasawarsa terakhir ini semakin subur dan meningkat. Sebagai sebuah konsekwensi logis, setiap timbul persoalan, penemuan maupun aktifitas baru sebagai produk dari kemajuan tersebut, umat senantiasa bertanya-tanya, bagaimanakah kedudukan hal tersebut dalam pendangan dan ajaran hukum Islam. ${ }^{1}$ Demikian halnya, dengan situasi wabah COVID-19 yang melanda 118 negara di dunia termasuk Indonesia.

Salah satu yang menjadi elemen fleksibilitas ajaran Islam adalah fatwa. Karakteristik fatwa umumnya bersifat responsif dan kasuistik yang diberikan

${ }^{1}$ Majelis Ulama Indonesia, 2011, Himpunan Fatwa Majelis Ulama Indonesia Sejak 1975, Jakarta, Erlangga, 2011, hlm. 3. 
oleh seorang ulama (faqih) kepada seseorang atau masyarakat yang mengajukan pertanyaan tentang hukum suatu kasus. Seorang ulama atau sekelompok ulama ketika ingin mengeluarkan fatwa harus mamahami betul jenis kasus yang diajukan oleh mustafti (orang yang mengajukan pertanyaan kepada ulama tentang hukum masalah yang dialami), tak hanya jenis kasus, tapi juga menyangkut siapa pelakunya, kapan kejadiannya, dimana dilakukan, dalam kondisi apa dilakukan, apa motivasi dan apa implikasi fatwa tersebut. Dari keterangan ini dipahami bahwa fatwa harus berangkat dari pertanyaan $5 \mathrm{~W} 1 \mathrm{H}$.

Teori fatwa menyebutkan bahwa dua kasus yang sama tidak serta merta harus diberi hukum yang sama, sebab, setiap kasus memiliki karakteristik masing-masing. Dengan demikian, perlu disosialisasikan bahwa hanya pengetahuan tentang kasuslah (fahm waqi) yang menjadi penentu kualitas fatwa, bukan dalil hukum (nash). Dalil hukum bertugas mengarahkan untuk mengetahui tujuan syariat (maqashid syariah) dari sumber hukum yaitu Allah SWT. Aturan berfatwa ini menjadi penting karena ketika tidak merujuk pada rule of the game (aturan main), kode etik, serta minimnya kalkulasi, maka bukan hanya satu atau dua persepsi yang muncul, tapi ratusan persepsi. ${ }^{2}$ Olehnya itu, MUI dituntut harus mampu meramu metode (manhaj) dalam berfatwa, sehingga dapat memberikan kemaslahatan bagi umat Islam.

Sejauh ini penelitian tentang metode talfiq manhaji dalam fatwa hanya dilakukan dengan pendekatan content analysis, untuk mengetahui substansi, relevansi dan kepentingan yang ada dibalik fatwa. Sebagaimana yang ditulis oleh Jamal Ma'mur dalam Peran Fatwa MUI dalam Berbangsa dan Bernegara (Talfiq Manhaji sebagai Metodologi Penetapan Fatwa MUI). Dari penelitian tersebut tampak bahwa talfiq manhaji dengan membandingkan Metode berfatwa atau berijtihad MUI dan metode penetapan (istinbath) Imam Madzhab yang merupakan sumber manhaj masih cenderung diabaikan. Oleh karena itu, penelitian ini berupaya untuk melengkapi beberapa penelitian terdahulu tentang talfiq manhaji dengan pendekatan perbandingan

\footnotetext{
${ }^{2}$ Abdul Rauf Amin, Epistimologi Fatwa, https://uinalauddin.ac.id/tulisan/detail/epistimologi-fatwa, diakses tanggal 2 April 2020.
} 
(muqaranah) dengan metode yang telah ditetapkan oleh para Imam Madzhab. Dengan demikian, dapat terlihat dengan jelas seberapa efektif metode talfiq manhaji dalam menjawab persoalan kontemporer, khususnya ditengah situasi wabah Covid-19 ini. Terdapat dua hal yang disasar dalam penelitian ini. Pertama, Metode talfiq manhaji dalam Fatwa MUI. Kedua, Membandingkan Metode Penetapan Fatwa MUI dan para Imam Madzhab.

Sejalan dengan itu, penelitian ini menggunakan jenis penelitian kualitatif yang dijelaskan secara deskriftif dengan metode kajian pustaka (library research). Penelitian ini menggunakan pendekatan Muqaranah madzahib (perbandingan madzhab) untuk mendeteksi perbedaan corak metodologi para ulama dalam menetapkan hukum dan pendekatan kontekstual digunakan untuk mengetahui setting sosial para ulama baik MUI maupun Imam Madzhab terkait hal yang melatarbelakangi sebuah fatwa menjadi sebuah produk hukum.

Objek penelitian ini fokus pada Fatwa MUI Nomor 17 Tahun 2020 tentang Pedoman Kaifiat Shalat bagi Tenaga Kesehatan yang Memakai Alat Pelindung Diri (APD) Saat Merawat dan Menangani Pasien COVID-19. Sebab, di dalam fatwa tersebut penulis menemukan metode talfiq manhaji yang menjadi alternatif terakhir dalam urutan metode aturan berfatwa MUI. Sumber data penelitian ini adalah sumber ilmu-ilmu keislaman, di antaranya literatur fiqh lintas mazhab, fiqh muqaran, kaidah fiqh, hadis, dan sejarah. Sumber data sekunder menggunakan literatur-literatur pendukung yang sesuai dengan fokus masalah yang dikaji, baik berupa literatur buku, artikel jurnal dan lain sebagainya.

Penelitian ini didasarkan pada sebuah paradigma pemikiran dimana kondisi dan situasi tidak memungkinkan untuk bertahan pada pendapat madzhab tertentu. Ambiguitas pada tataran tertentu melemahkan umat untuk beramal dan berkreasi. Implikasinya adalah talfiq manhaji akan memberi warna baru dalam khazanah keilmuan Islam, dan menjadi salah satu metode paling cepat serta dapat dipertanggung jawabkan dalam merespon persoalan kekinian yang membutuhkan jawaban. 


\section{B. Pembahasan}

\section{Metode Talfiq Manhaji dalam Fatwa MUI Nomor 17 Tahun 2020}

Dalam historiografi Indonesia, ulama memerankan posisi penting dalam dinamika kehidupan masyarakat. Ulama, yang merupakan sebutan bagi seseorang yang memiliki pemahaman agama (Islam) yang mendalam, selalu ikut dalam proses kehidupan masyarakat, baik dalam bidang sosial, politik, kultural, dan persoalan keagamaan ${ }^{3}$. Dalam sejarahnya, otoritas keagamaan mengalami fragmentasi yang sangat jelas. Majelis Ulama Indonesia, misalnya, yang didirikan pada Juli 1975, mengalami fase yang dinamis. Awalnya, keberadaan MUI memiliki fungsi sebagai penyambung lidah antara kepentingan pemerintah dan komunitas Islam (baik NU, Muhammadiyah dan lainnya) bergeser menjadi tangan panjang kepentingan pemerintahan Orde Baru. Pergeseran itu tidak berhenti sampai di sana. Zulkifli mencatat bahwa telah terjadi pergeseran orientasi MUI, sebagai salah satu lembaga yang memproduksi fatwa, yang awalnya state-oriented perlahan bergeser menjadi ummah-oriented. ${ }^{4}$

Salah satu Fatwa MUI yang bersifat ummah-oriented adalah Fatwa Nomor 17 Tahun 2020 tentang Pedoman kaifiat shalat bagi tenaga kesehatan yang memakai alat pelindung diri (APD) saat merawat dan menangani pasien covid-19. Dalam fatwa tersebut MUI mengeluarkan fatwa yang membedakan kondisi Faqidu ath-Thahurain (kondisi sulit mengakses media air dan tanah untuk bersuci) dan pakaian yang terkena najis. Mayoritas ulama memasukkan kategori suci hadas dan najis ke dalam syarat sah salat. Di dalam fatwa MUI tentang pedoman salat tenaga kesehatan yang memakai alat pelindung diri (APD) saat menangani pasien COVID-19 bahwa dalam kondisi hadas dan tidak mungkin bersuci, seperti wudhu atau tayamum, tenaga kesehatan boleh melaksanakan salat dalam kondisi tidak suci dan tidak perlu mengulangi shalatnya (poin 8). Dalam kondisi APD yang dipakai terkena najis dan tidak memungkinkan untuk

${ }^{3}$ Zulkifli, "The Ulama in Indonesia: Between Religious Auhtority and Symbolic Power", Jurnal Miqot, Vol. XXXVII, No. 1, Januari - Juni 2013, hlm. 181.

${ }^{4}$ Zulkifli, op.Cit., hlm. 186. 
dilepas atau disucikan, tenaga kesehatan boleh melaksanakan salat dalam kondisi tidak suci dan mengulangi salat (i'adah) setelah bertugas (poin 9). Fatwa yang dikeluarkan MUI ini membedakan kondisi hadas dan kondisi pakaian yang terkena najis. Dalam kondisi hadas [poin 8], MUI mengikuti pendapat yang terkuat dalilnya menurut an-Nawawi, yakni salatnya tidak perlu diulang 5 .

Sedangkan dalam kondisi pakaian terkena najis [poin 9], MUI mengikuti pendapat mayoritas dalam mazhab Syafi'i yaitu salatnya harus diulang usai bertugas atau dalam kondisi normal. Metode yang digunakan MUI dalam fatwa ini adalah Talfiq manhaji yaitu menggabungkan metode istinbat para Imam Madzhab dalam kondisi hadas dan najis yang tidak memungkinkan para petugas medis untuk beribadah sesuai ketentuan normatifnya.

Meskipun mayoritas masyarakat Indonesia bermadzhab Syafi'i. Namun, pada kondisi ini seseorang harus berani mengambil risiko untuk berbeda pendapat dengan Imam Syafi'i dalam tataran hasil pemikiran, meskipun dalam manhaj kebanyakan mengikutinya. Ulama yang mengikuti metodologi yang dipakai Imam Syafi'i, menurut Qodry azizi masih tetap dianggap sebagai pengikut madzhab Syafi'i meskipun dalam pendapat operasionalnya mempunyai perbedaan dengan imamnya. Dalam mempraktekkan talfiq fil manhaj (menggabungkan metodologi imam madzhab) berarti sudah mempraktekkan ijtihad.

Dalam pandangan Qodri Azizy, apabila dirunut sejarahnya, metodologi dari tiap-tiap mazhab itu tidak stagnan namun terjadi dialektik. Konsep ijtihad fi al-manhaj inilah yang dipraktekkan oleh ulama Syafi'iyah periode awal dan sampai saat ini masih dapat dikembangkan, serta masih tetap disebut sebagai pengikut mazhab Syafi'i. Demikian pula jika dipraktekkan oleh ulama Hanafiyah dan ulama pengikut mazhab lainnya.

${ }^{5}$ Abi Zakariyah Yahya Bin Syaraf Al Nawawi, Syarah Shahih Muslim, Maktabah Taufiqiah, Damaskus, hlm. 103. 
Dalam biografinya, imam Syafi'i selalu menolak jika ilmu dan karyanya dinisbahkan kepada beliau ${ }^{6}$.

Dengan demikian, tidak harus mengikuti pendapat imam mazhab dari kata per kata, namun dapat juga melalui metodologinya ( $f i$ al-manhaj) bahkan juga untuk pengembangan metodologinya, bukan hanya mengikuti metodologi yang sudah ada. Jika ini disepakati, maka bukan saja terikat untuk mengikuti pendapat Syafi'i melalui karya primernya, namun juga dapat berbeda pendapat dengannya asalkan manhajnya tetap mengikutinya. Jika ini yang dipakai maka konsep talfiq harus direvisi, tidak seperti apa yang dipahami selama ini.

\section{Metode Penetapan Fatwa MUI}

Secara umum, MUI telah menyusun Pedoman Penetapan Fatwa Majelis Ulama Indonesia Nomor: U-596/MUI/X/1997. Secara operasional, pedoman fatwa MUI menetapkan empat ketentuan dasar. Pertama, setiap keputusan harus mempunyai dasar atas Kitabullah dan Sunnah Rasul yang mu'tabarah. Kedua, jika tidak terdapat pada kitabullah dan sunah rasul sebagaimana ditentukan pada pasal 2 ayat 1, keputusan fatwa hendaklah tidak bertentangan dengan ijma' dan qiyas mu'tabarah serta dalil-dalil hukum yang lain seperti istihsan, masalih mursalah, dan sad az-zariah. Ketiga, sebelum memutuskan fatwa, terlebih dahulu menelusuri pendapat imam madzhab terdahulu, baik yang berkaitan dengan dalil hukum atau dalil pihak yang berbeda pendapat. Dalam hal ini, jika material hukumnya berbeda, maka yang ditempuh adalah menganalogikan hukum material yang telah diputuskan ulama madzhab dengan mendeteksi kesamaan illat. Jikapun tidak memungkinkan, maka metodologi para imam madzhab diadopsi menjadi pisau analisis untuk memecahkan persoalan. Keempat, fatwa MUI selalu mempertimbangkan pandangan ahli yang relevan sesuai bidang kajian. Masalah kontemporer seperti wabah Covid-19 dengan pakaian Alat Pelindung Diri (APD) saat bertugas adalah persoalan yang mengharuskan hadirnya para pakar medis.

\footnotetext{
${ }^{6}$ A. Qodri Azizy, 2003, Reformasi Bermadzhab, Teraju, Jakarta, hlm. 25.
} 
Secara metodologis, proses penetapan hukum di Komisi Fatwa MUI ada lima tahapan. Pertama, sebelum mengeluarkan fatwa, terlebih dahulu meninjau pendapat para imam madzhab dalam masalah yang dikaji secara serius berikut dalil-dalilnya. Kedua, masalah-masalah yang jelas hukumnya (qath'iyyat) ditetapkan apa adanya. Hal ini adalah bukti dari manifestasi pendekatan nash qath'i, qauli dan manhaji. Ketiga, dalam masalah yang diperselisihkan ulama madzhab, diselesaikan dengan dua cara. Pertama, menemukan titik temu dengan metode al-jam'u wa attaufiq (menggabungkan dan menyesuaikan persamaan). Kedua, menggunakan tarjih (memilih pendapat yang paling kuat argumentasinya) melalui metode perbandingan madzhab dengan menggunakan kaidah ushul fiqh perbandingan.

Keempat, masalah yang tidak ditemukan hukumnya dalam madzhab, maka ditetapkan dengan ijtihad jama'i (kolektif) dengan metode bayani, ta'lili (qiyasi, istihsani, ilhaqi), istishlahi, dan sad az-zari'ah. Kelima, fatwa harus selalu memperhatikan kemaslahatan umum (mashalih ammah) dan tujuan syariat Islam (maqashid syariah) ${ }^{7}$.

\section{Metode Penetapan Fatwa Imam Mujtahidin}

Berikut pemaparan metode penetapan (istinbath) 4 Imam Madzhab: a.Imam Abu Hanifah

Metode yang digunakan Abu Hanifah dalam menetapkan hukum (istinbath) berdasarkan pada tujuh hal pokok:

1) Al-Qur'an sebagai sumber dari segala sumber hukum.

2) Sunah Rasul sebagai penjelasan terhadap hal-hal global yang ada dalam al-Qur'an.

3) Fatwa sahabat (aqwal al-shahabah) karena sahabat menyaksikan turunnya ayat dan mengetahui asbab al-nuzul al-Qur'an serta $a s b a b$ al-wurud hadis dan para perawinya. Sedangkan fatwa para tabi in tidak memiliki kedudukan sebagaimana fatwa sahabat.

\footnotetext{
${ }^{7}$ M. Asrorun Ni'am Sholeh, Metodologi Penetapan Fatwa Majelis Ulama Indonesia, hlm.
} 122-129. 
4) Qiyas (analogi) yang digunakan apabila tidak ada nash sharih dalam al- Qur'an, hadis maupun aqwal al-shahabah.

5) Istihsan yaitu berpalingnya seorang mujtahid dari tuntutan qiyas jali (nyata) kepada qiyas khafi (samar) atau dari hukum kulli (umum) kepada hukum Istitsnaiy (pengecualian) karena ada dalil yang menyebabkan dia memilih dan memenangkan perpalingan ini.

6) Ijmak yaitu kesepakatan para mujtahid dalam suatu kasus hukum pada suatu masa tertentu.

7) 'Urf yaitu adat kebiasaan yang telah dikenal orang banyak dan telah menjadi tradisi, baik berupa perkataan, perbuatan atau keadaan.

b. Imam Malik

Metode yang digunakan Imam Malik dalam menetapkan hukum (istinbath):

1) Al-Quran: Dalam berpegang kepada al-Qur'an ini, pengambilan hukum berdasarkan atas zahir nash al-Qur'an atau keumumannya, meliputi mafhum al-Mukhalafah dan mafhum al-Aula' dengan memperhatikan 'illatnya. ${ }^{8}$

2) Sunnah: Dalam berpegang kepada Sunnah sebagai dasar hukum, Imam Malik mengikuti cara yang dilakukannya dalam berpegang kepada al-Quran.

3) Ijma' Ahl Madinah: Yaitu ijma' ahl Madinah yang berasal dari dalil an-naql, hasil dari mencontoh Rasulullah Saw, bukan dari hasil ijtihad ahl Madinah. ${ }^{9}$

4) Fatwa Sahabat: Yang dimaksud dengan fatwa sahabat disini adalah sahabat besar, yang mana pengetahuan terhadap suatu masalah disandarkan pada an-naql. ${ }^{10}$

5) Khabar ahad dan Qiyas: Imam Malik tidak mengakui khabar ahad sebagai sesuatu yang datang dari Rasulullah, jika khabar ahad itu

${ }^{8}$ Haswir dan Muhammad Nurwahid, 2006, Perbandingan Mazhab, Realitas Pergulatan Pemikiran Ulama Fiqih, Alaf Riau, Pekanbaru, hlm. 88.

${ }^{9}$ Haswir dan Muhammad Nurwahid, op.cit., hlm. 89. hlm. 108.

${ }^{10}$ Huzaemah Tahido Yanggo, 1997, Pengantar Perbandingan Mazhab, Logos, Jakarta, 
bertentangan dengan sesuatu yang sudah dikenal oleh masyarakat Madinah, sekalipun hanya dari hasil istinbath, kecuali khabar ahad tersebut dikuatkan oleh dalil-dalil lain yang qath'i. Dalam menggunakan khabar ahad ini, Imam Malik tidak selalu konsisten. Kadang-kadang ia mendahulukan qiyas dari pada khabar ahad. ${ }^{11}$

6) Al-Istihsan: Yakni beralih satu qiyas ke qiyas lain yang dianggap lebih kuat dilihat dari tujuan syariat diturunkan. Artinya jika terdapat satu masalah yang menurut qiyas semestinya diterapkan hukum tertentu, tetapi dengan hukum tertentu itu ternyata akan menghilangkan suatu mashlahah atau membawa madharat tertentu, maka ketentuan qiyas yang demikian itu harus dialihkan ke qiyas lain yang tidak akan membawa kepada akibat negative. ${ }^{12}$

7) Al-Maslahah Mursalah: Maslahah yang tidak ada ketentuannya, baik secara tersurat atau sama sekali tidak disinggung oleh nash. Dengan demikian maslahah mursalah itu kembali kepada memelihara tujuan syari'at diturunkan.

8) Sad Az-Zariah: Imam Malik menggunakan Sad Az-Zariah sebagai landasan dalam menentapkan hukum. Menurutnya, semua jalan atau sebab yangmenuju kepada yang haram atau terlarang, hukumnya haram atau terlarang. Semua jalan atau sebab yang menuju kepada yang halal, halal pula hukumnya. ${ }^{13}$

9) Istishhab: Yakni tetapnya suatu ketentuan hukum untuk masa sekarang atau yang akan datang, berdasarkan atas ketentuan hukum yang sudah ada di masa lampau. Misalnya: seorang yang telah yakin sudah berwudhu dan dikuatkan lagi bahwa ia baru saja menyelesaikan shalat subuh, kemudian datang keraguan kepada orang tersebut tentang sudah batal atau belum wudhunya, maka hukum yang dimiliki oleh orang tersebut adalah bahwa belum batal wudhunya. ${ }^{14}$.

\footnotetext{
${ }^{11}$ Haswir dan Muhammad Nurwahid, op.cit., hlm. 91.

${ }^{12}$ Huzaemah Tahido Yanggo, op.cit., hlm. 109.

${ }^{13}$ Huzaemah Tahido Yanggo,op.cit., hlm. 112.

${ }^{14}$ Haswir dan Muhammad Nurwahid, op.cit., hlm. 95.
} 
10) Syar'u Man Qablana Syar'un Lana: Menurut Qadhy Abd. Wahab al-Maliky, bahwa Imam Malik menggunakan qaidah syar'un man qablana syar'un lana sebagai dasar hukum. Tetapi menurut Sayyid Muhammad Musa, tidak ditemukan secara jelas pernyataan Imam Malik yang menyatakan demikian ${ }^{15}$.

c. Imam Syafi'i

Metode yang digunakan Imam Syafi'I dalam menetapkan hukum (istinbath)

1) Al-Quran: Imam Asy-Syafi'i menetapkan bahwa al-Qur'an merupakan sumber hukum Islam yang paling pokok, bahkan beliau berpendapat. "Tidak ada yang diturunkan kepada penganut agama manapun, kecuali petunjuknya terdapat dalam al-Qur'an.”. Oleh karena itu, Imam Asy-Syafi'i senantiasa mencantumkan nash-nash al-Qur'an setiap kali mengeluarkan pendapatnya sesuai metode yang digunakannya, yakni deduktif. ${ }^{16}$

2) Sunnah Rasul: Imam al-Syafi'i berkata,'Semua yang datang dari sunnah merupakan penjelasan dari al-Qur'an. Maka setiap orang yang menerima al-Qur'an, maka wajib menerima sunnah Rasulullah, karena Allah SWT mewajibkan hamba-Nya untuk mentaati Rasul-Nya dan mematuhi hukum-hukumnya. Orang yang menerima apa yang datang dari Rasulullah SAW berarti ia telah menerima apa yang datang dari Allah SWT, karena Allah telah mewajibkan kepada manusia untuk mentaatinya". ${ }^{17}$

3) Ijma': Ijma' merupakan kesepakatan Imam-imam mujtahid yang ada dalam suatu masa tertentu. Ijma' tidak terjadi ketika nabi masih hidup, karena Nabi senantiasa menyepakati perbuatan-perbuatan para sahabat yang dipandang baik, dan itu dianggap sebagai syari'at $^{18}$. Ijma' merupakan urutan ketiga dalam sumber hukum

${ }^{15}$ Huzaemah Tahido Yanggo, op.cit., hlm. 113.

${ }^{16}$ Rahmat Syafe'i, 2010, Ilmu Ushul Fiqh, Pustaka Setia, Bandung, hlm. 52. hlm. 32-33.

${ }^{17}$ Imam Abu Abdillah Muhammad bin Idris Asy-Syafi'i, al-Risalah, Al-Ilmiyah, Mesir,

${ }^{18}$ Rahmat Syafe'i, op.cit., hlm. 71. 
Islam setelah al-Qur'an dan as-Sunnah. Kendati demikian, dasar ijma' tetap mengacu pada landasan dalil-dalil yang terdapat dalam al-Qur'an dan as-Sunnah. ${ }^{19}$

4) Qiyas: Qiyas menjadi dasar pengambilan hukum yang ke empat menurut Imam Asy-Syafi'i. Qiyas secara umum yaitu proses penyingkapan kesamaan hukum suatu kasus yang tidak disebutkan dalam suatu nash, dengan suatu hukum yang disebutkan dalam nash karena adanya kesamaan dalam illat-nya ${ }^{20}$. Beliau adalah orang pertama yang membicarakan qiyas dengan patokan kaidanya dan menjelaskan asas-asasnya. Beliau memilih metode qiyas seperti memberikan kerangka teoritis dan metodologinya dalam bentuk kaidah rasional namun tetap praktis. Menurutnya ijtihad itu sama dengan qiyas.

\section{d. Imam Ahmad Bin Hambal}

Metode yang digunakan imam Ahmad bin Hambal dalam menetapkan hukum sebagai berikut:

1) Al-Quran dan Sunnah (Shahih): Menurut Ibn Qayyim, jika suatu persoalan yang menghendaki pemecahan hukum, maka pertamatama ia harus mencari jawaban persoalan tersebut kepada nash, maka wajib menetapkan hukum berdasarkan nash tersebut. ${ }^{21}$

2) Fatwa Sahabat: Imam Ahmad bin Hanbal menjadikan fatwa sahabat sebagai standar hukum nomor tiga setelah Alquran dan sunnah karena menurutnya fatwa sahabat diambil dari hadis shahih. Dalam hal ini ulama yang banyak mengeluarkan fatwa adalah Umar bi alKhattab, Ali bin Abi Thalib, Abdullah bin Abi Mas'ud, Abbbdullah bin Abbas, Zaid bin Tsabit, Sayyidah Aisyah serta Abu Bakr, Usman bin Affan, Muaz bin Jabal, Sa'ad bin Abi Waqqas, Thalhah bin ABi Ubaidillah, Zubair bin Awwam, Abdullah bin Umar dan

\footnotetext{
${ }^{19}$ Imam Abu Abdillah Muhammad bin Idris Asy-Syafi'i, tth, Kitab Al-Umm, Jilid 5, Dar alKutub al-Ilmiyah, hlm. 26.

${ }^{20}$ Rahmat Syafe'i, op.cit., hlm. 87.

${ }^{21}$ Ibnu Qayyim al-Jauziyah, 1991, I'lam al-Muwaqqi'in, Dar al-Kutub al-'Ilmiyah, hlm. 9.
} 
Salman al-Farisi adalah sahabat yang tidak terlalu banyak mengeluarkan fatwa. ${ }^{22}$

3) Hadis mursal dan dhaif: Hadis mursal dan hadus dhaif jika tidak ada dalil yang menguatkannya dan didahulukan daripada qiyas. Hadis mursal, hadis dhaif. Adapun hadis dhaif menurut Imam Hambal bukanlah hadis batil atau munkar atau perawinya yang dituduh dusta serta tidak boleh diambil hadisnya namun yang beliau maksud dengan kandungan hadis dhaif adalah orang yang belum mencapai derajat tsiqah tetapi tidak sampai dituduh berdusta dan jika memang demikian maka iapun bagian dari hadis shahih. ${ }^{23}$

4) Qiyas: Jika tidak ada nash dari al-Qur'an dan sunnah, atau pendapat sahabat atau hadits mursal atau hadits dhaif maka beliau baru mengambil qiyas, tapi dalam hal ini imam hambali hanya mengambil qiyas yang berasal dari ulama terdahulu. ${ }^{24}$

Metode Penetapan Hukum antara MUI dan Imam Madzhab dapat dilihat dari tabel berikut:

Tabel 1.

\begin{tabular}{|c|c|c|c|}
\hline No & Madzhab & $\begin{array}{c}\text { Dasar } \\
\text { Penetapan Hukum }\end{array}$ & Metodologi \\
\hline 1 & MUI & $\begin{array}{l}\text { 1. Al-Quran } \\
\text { 2. Sunnah, } \\
\text { 3. Ijma' } \\
\text { 4. Qiyas } \\
\text { 5. Istihsan } \\
\text { 6. Masalih Mursalah } \\
\text { 7. Sad Az-Zariah } \\
\end{array}$ & $\begin{array}{l}\text { 1. Meninjau Pendapat Imam } \\
\text { Madzhab. } \\
\text { 2. Pendekatan Nash Qathi, } \\
\text { Qauli dan Manhaji. } \\
\text { 3. Metode al-jam'u wa attaufiq } \\
\text { 4. Metode Tarjih }\end{array}$ \\
\hline 2 & Hanafi & $\begin{array}{l}\text { 1. Al-Qur'an } \\
\text { 2. Sunah } \\
\text { 3. Pendapat sahabat } \\
\text { 4. Qiyas } \\
\text { 5. Istihsan } \\
\text { 6. Ijma' } \\
\text { 7. 'Urf }\end{array}$ & $\begin{array}{l}\text { 1. Metode Nasakh } \\
\text { 2. Metode Tarjih } \\
\text { 3. Metode al-jam 'u wa attaufiq } \\
\text { 4. Metode Tasaqut dalilain }\end{array}$ \\
\hline
\end{tabular}

\footnotetext{
${ }^{22}$ Ahmad Kholik, 2009, Melacak Sejarah Metodologi Ijtihad, Shahifah, Bandung, hlm. 224.

${ }^{23}$ Mustofa as-Saq'ah, 1998, Imam Ahmad bin Hanbal, Dar al-Kitab, Beirut, hlm. 220.

${ }^{24}$ Ibid., hlm. 224.
} 


\begin{tabular}{|c|c|c|c|}
\hline 3 & Maliki & $\begin{array}{l}\text { 1. Al-Qur'an } \\
\text { 2. Sunah } \\
\text { 3. Ijma' Ahl Madinah } \\
\text { 4. Fatwa Sahabat } \\
\text { 5. Khabar ahad dan qiyas } \\
\text { 6. Al-Istihsan } \\
\text { 7. Al-Maslahah Mursalah } \\
\text { 8. Sad az-Zariah } \\
\text { 9. Istishab } \\
\text { 10. Syar'u Man Qablana }\end{array}$ & $\begin{array}{l}\text { 1. Metode al-jam'u wa attaufiq } \\
\text { 2. Metode Tarjih } \\
\text { 3. Metode Nasakh } \\
\text { 4. Metode Tasaqut dalilain }\end{array}$ \\
\hline 4 & Syafi'i & $\begin{array}{l}\text { 1. Al-Qur'an } \\
\text { 2. Sunah } \\
\text { 3. Pendapat sahabat } \\
\text { 4. Qiyas }\end{array}$ & $\begin{array}{l}\text { 1. Metode al-jam'u wa attaufiq } \\
\text { 2. Metode Tarjih } \\
\text { 3. Metode Nasakh } \\
\text { 4. Metode Tasaqut dalilain }{ }^{25}\end{array}$ \\
\hline 5 & Hambali & $\begin{array}{l}\text { 1. Al-Qur'an } \\
\text { 2. Sunah } \\
\text { 3. Fatwa Sahabat } \\
\text { 4. Hadis Mursal dan Dhaif } \\
\text { 5. Qiyas }\end{array}$ & $\begin{array}{l}\text { 1. Metode al-jam'u wa attaufiq } \\
\text { 2. Metode Tarjih } \\
\text { 3. Metode Nasakh } \\
\text { 4. Metode Tasaqut dalilain }\end{array}$ \\
\hline
\end{tabular}

Tabel di atas menunjukkan bahwa metode yang digunakan MUI dalam menetapkan hukum serta metodologi yang digunakan memungkinkan untuk talfiq fil manhaj, karena dalam operasionalnya merujuk pada metode yang telah dilakukan oleh empat imam madzhab.

\section{Penutup}

Talfiq manhaji yang digunakan MUI pada pedoman shalat bagi petugas kesehatan di masa COVID-19, dengan membedakan situasi serta kondisi petugas kesehatan, memberikan kemudahan bagi umat Islam yang berada pada kondisi yang sama dengan petugas kesehatan seperti dokter, perawat, bahkan relawan saat wabah COVID-19 adalah orang-orang yang rentan terinfeksi COVID-19, sementara, petugas medis berada di garda terdepan dalam penanganannya. Metode MUI dalam penetapannya sangat memperhatikan kekuatan dalil dan prinsip kemaslahatan umum.

Talfiq manhaji ini merupakan lonjakan paradigma yang sangat relevan untuk dikembangkan guna mengukuhkan ragam metode yang sudah ada. Dalam talfiq manhaji tidak dikenal fanatisme madzhab. Justru, yang ditekanlah

${ }^{25}$ Wahbah Al-Zuhaili, 2005, Ushul al-Fiqh al-Islami, Dar al-Fiqh, Damsyiq, hlm. 1182 - 
adalah inklusivitas, moderasi serta akomodasi dari empat madzhab yang popular dengan metode yang telah dibukukan. Talfiq manhaji juga diperlukan agar hukum Islam mampu menjawab tantangan zaman, memberikan kontribusi positif pada kehidupan konkrit manusia. Serta mampu membangun citra dirinya, sehingga klaim Islam yang shalih li kulli zaman wa makan dapat terwujud.

Kajin ini masih memiliki banyak keterbatasan, khususnya pada ranah metode pengembangan pasca imam madzhab. Hal ini diperlukan, untuk melihat lebih jauh genealogi metode pemikiran hukum Islam dari masa ke masa, sehingga mampu mendeteksi metode efektif ditiap zaman yang berbeda.

\section{DAFTAR PUSTAKA}

Al - Jauziyah, Ibnu Qayyim, 1991, I'lam al-Muwaqqi'in, Dar al-Kutub al-'Ilmiyah. Al Nawawi, Abi Zakariyah Yahya Bin Syaraf Al Nawawi, Syarah Shahih Muslim, Maktabah Taufiqiah, Damaskus.

Al-Zuhaili, Wahbah, 2005, Ushul al-Fiqh al-Islami, Dar al-Fiqh, Damsyiq.

As-Saq'ah, Mustofa, 1998, Imam Ahmad bin Hanbal, Dar al-Kitab, Beirut.

Asy-Syafi'i, Imam Abu Abdillah Muhammad bin Idris, 1312 H, al-Risalah. alIlmiyah, Mesir.

Asy-Syafi'i, Imam Abu Abdillah Muhammad bin Idris, tth, Kitab Al-Umm Jilid 5. Dar al-Kutub al-Ilmiyah, Beirut.

Azizy, A. Qodri, 2003, Reformasi Bermadzhab, Teraju, Jakarta.

Haswir dan Muhammad Nurwahid, 2006, Perbandingan Mazhab, Realitas Pergulatan Pemikiran Ulama Fiqih, Alaf Riau, Pekanbaru.

Kholik, Ahmad, Melacak Sejarah Metodologi Ijtihad. 2009, Shahifah, Bandung.

Majelis Ulama Indonesia, 2011, Himpunan Fatwa Majelis Ulama Indonesia Sejak 1975, Jakarta, Erlangga.

Sholeh, M. Asrorun Ni'am, Metodologi Penetapan Fatwa Majelis Ulama Indonesia.

Syafe'i, Rahmat, 2010, Ilmu Ushul Fiqh, Pustaka Setia, Bandung.

Yanggo, Huzaemah Tahido, 1997, Pengantar Perbandingan Mazhab, Logos, Jakarta. 
Zulkifli, "The Ulama in Indonesia: Between Religious Auhtority and Symbolic Power", Jurnal Miqot, Vol. XXXVII, No. 1, Januari - Juni 2013.

\section{Internet}

Amin, Abdul Rauf, Epistimologi Fatwa, https://uinalauddin.ac.id/tulisan/detail/epistimologi-fatwa, diakses tanggal 2 April 2020.

Majelis Ulama Indonesia, Fatwa Penyelenggaraan Ibadah dalam Situasi Terjadi Wabah COVID 19, https://mui.or.id/berita/27674/fatwa-penyelenggaraanibadah-dalam-situasi-terjadi-wabah-covid-19/, diakses tanggal 1 April 2020.

Majelis Ulama Indonesia, Fatwa No 17 Tahun 2020 - Pedoman Kaifiat Shalat bagi Tenaga Kesehatan yang Memakai Alat Pelindung Diri (APD) saat Merawat dan Menangani Pasien COVID-19, https://mui.or.id/produk/fatwa/27748/fatwa-no-17-tahun-2020-pedomankaifiat-shalat-bagi-tenaga-kesehatan-yang-memakai-alat-pelindung-diriapd-saat-merawat-dan-menangani-pasien-covid-19/, diakses tanggal 1 April 2020.

Majelis Ulama Indonesia, Fatwa No 18 Tahun 2020 - Pedoman Pengurusan Jenazah (Tajhiz Al-Jana'iz) Muslim yang Terinfeksi COVID-19, https://mui.or.id/produk/fatwa/27752/fatwa-no-18-tahun-2020-pedomanpengurusan-jenazah-tajhiz-al-janaiz-muslim-yang-terinfeksi-covid-19/, diakses tanggal 1 April 2020. 